\title{
ULTRASTRUCTURE OF NORMAL RAT SYNOVIAL MEMBRANE
}

\author{
BY \\ S. ROY AND F. N. GHADIALLY \\ From the Department of Pathology, University of Sheffield
}

Electron microscopic study of synovial membranes of many animal species has added materially to our understanding of the structure and function of this organ. The fine structure of the synovium of man (Barland, Novikoff, and Hamerman, 1962; Roy, Ghadially, and Crane, 1966), guinea-pig (Wyllie, More, and Haust, 1964), rabbit (Ghadially and Roy, 1966), calf and dog (Langer and Huth, 1960), and cat (Lever and Ford, 1958) have been well documented, but rat synovium has not been studied in this fashion. During the course of our investigations of normal and pathological synovia we had occasion to examine the synovium of this animal and found that it shows some features quite unlike any that have been observed in other species. It is therefore worthwhile to report these findings.

\section{Material and Methods}

Synovial membrane was collected from the right knee joints of eight normal rats weighing between 200 and
$250 \mathrm{~g}$. The animals were killed with a blow on the head. The quadriceps above the patella were divided and after reflecting the patella, a small piece of synovium measuring about $4 \times 2 \mathrm{~mm}$. was promptly removed from the infrapatellar region. The tissue was spread out on a piece of filter paper and dropped in buffered cold osmium tetroxide (Palade, 1952). It was fixed for 2 hours at $4^{\circ} \mathrm{C}$. and then cut into thin strips about $1 \mathrm{~mm}$. wide. The synovial membrane with a minimum of subsynovial tissue was dissected off the filter paper leaving behind most of the fibro-fatty subsynovial tissue which would have otherwise interfered with the cutting of ultra-thin sections. The synovial tissue was processed according to the method of Glauert (1961) and orientated by the method of Coulter (1962). Sections were cut with the Porter Blum microtome, mounted on uncoated copper grids, stained with lead citrate (Reynolds, 1963), and examined under the A.E.I. E.M.6 using an accelerating voltage of 50 or $75 \mathrm{Kv}$.

Another piece of synovium was collected from the opposite knee, fixed in formalin, and processed for light microscopy using haematoxylin and eosin stain.

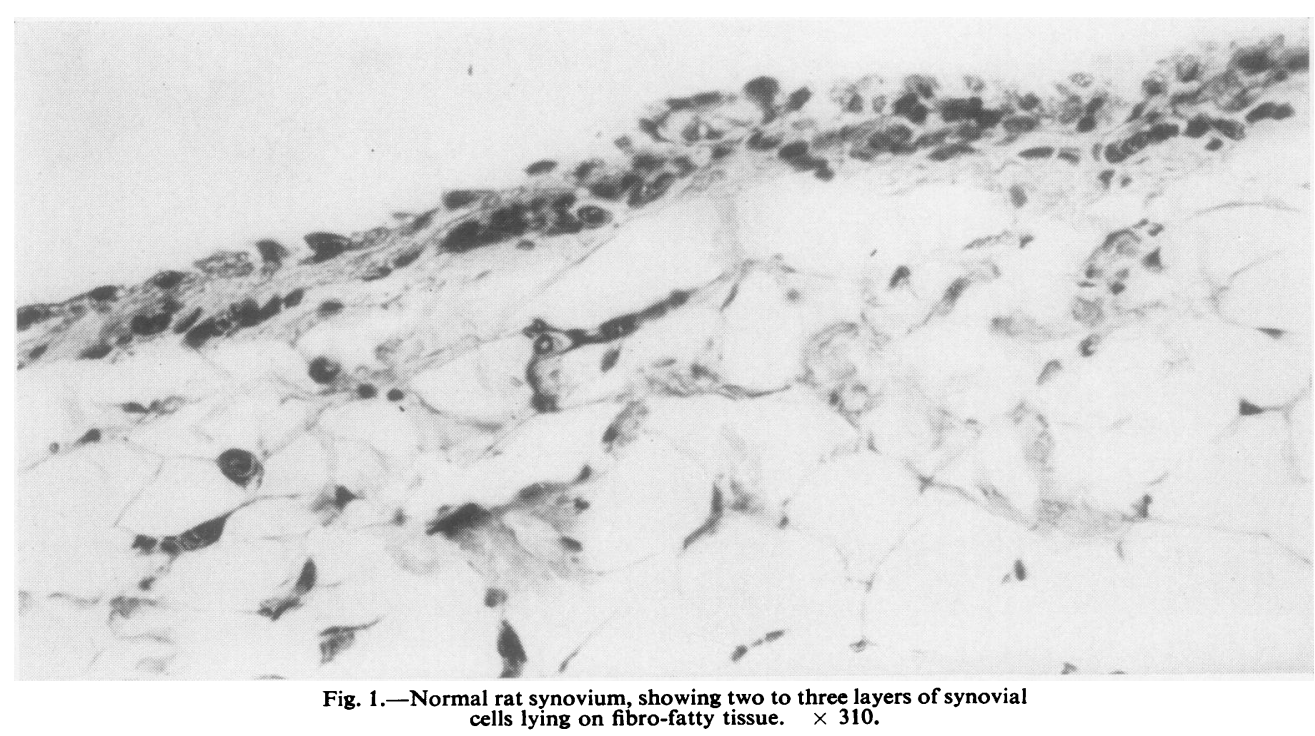




\section{Results}

\section{Light Microscopy}

The normal rat synovium in this region shows one to three layers of small oval or polygonal synovial lining cells lying on a predominantly fatty subsynovial tissue (Fig. 1).

\section{Electron Microscopy}

The lining cells of the normal rat synovium form a more or less continuous layer on the surface (Fig. 2).

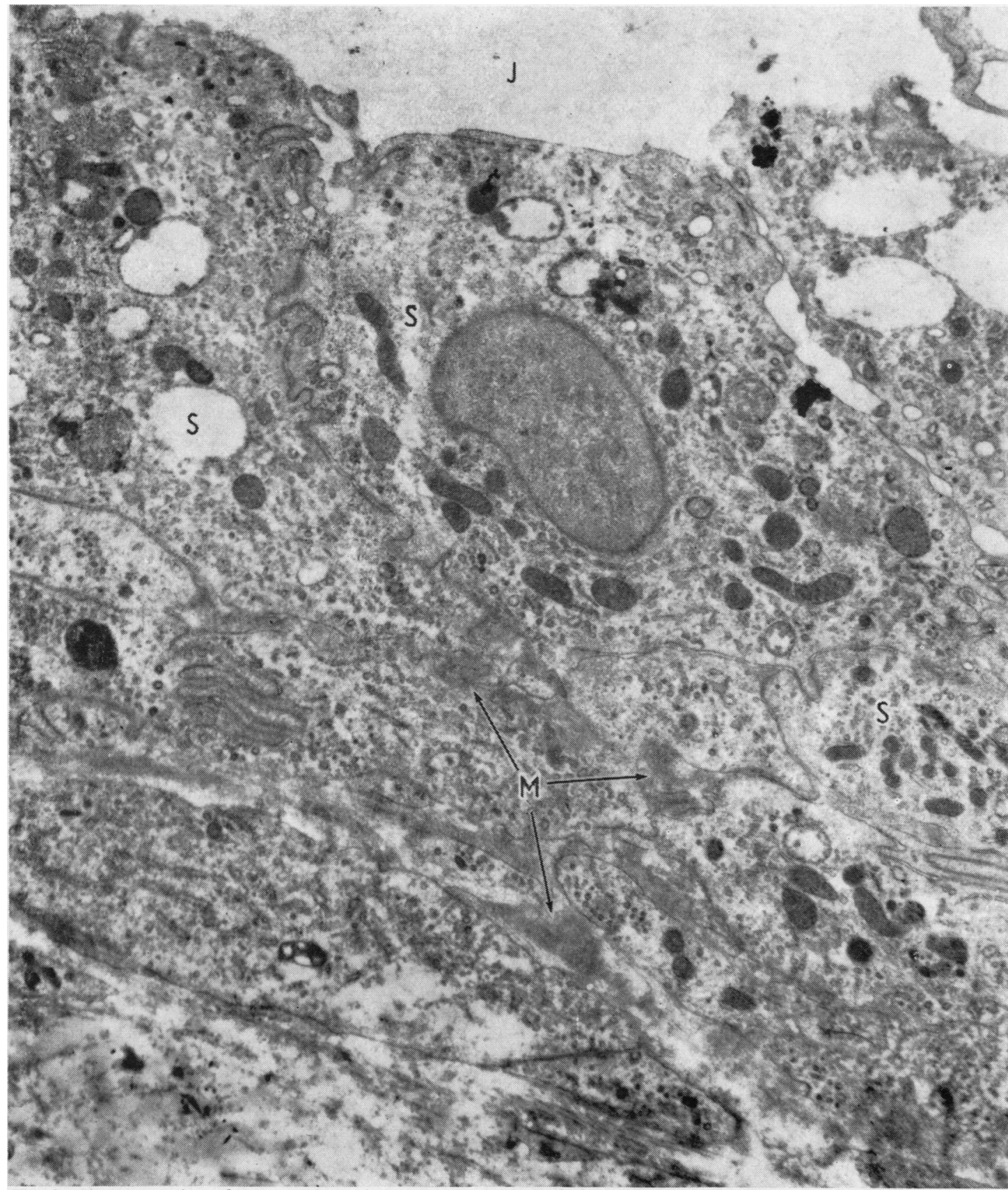

Fig. 2.-Low-power view of rat synovium, showing many closely packed synovial cells (S) and small pockets of matrix (M) Joint space $(\mathrm{J}) . \quad \times \mathbf{8 , 0 0 0}$ 
Although most of the cells are closely apposed to each other, at places the cells are separated by small amounts of moderately electron dense matrix. Sometimes spaces resembling canaliculi are seen at the junction of three or more cells and this appearance is further enhanced by the occurrence of filamentous cell processes projecting into these spaces (Fig. 3). Whether these are true canaliculi or just intercellular spaces containing electron lucent matrix is not clear.

Syrovial Cells.-These can be broadly divided into two types similar to those found in man (Barland and others, 1962; Roy and others, 1965) and rabbit (Ghadially and Roy, 1966). Type A cells showed prominent Golgi apparatus, many small smoothwalled vesicles, large vacuoles, and filopodia but little rough endoplasmic reticulum (Fig. 4, opposite).

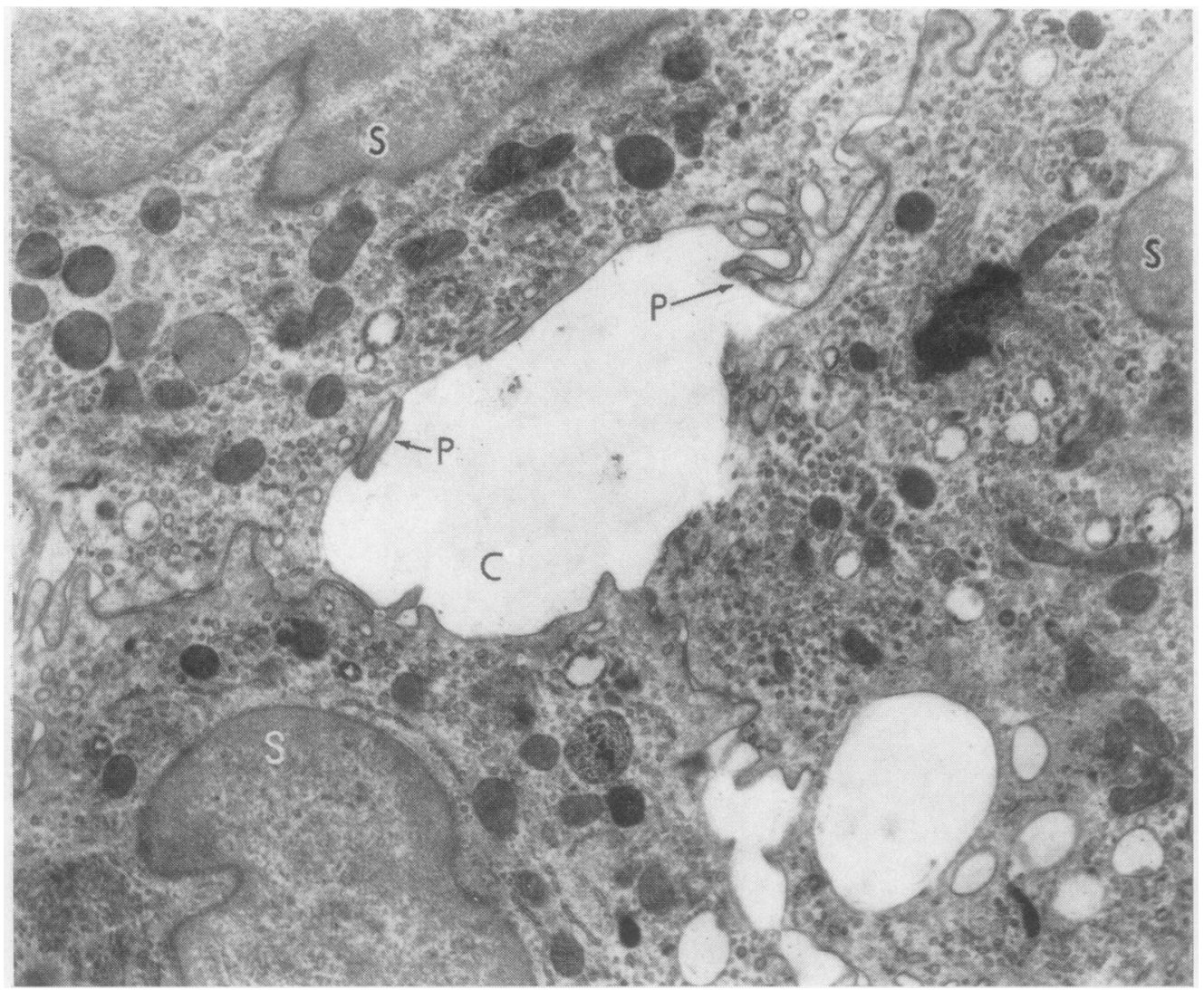

Fig. 3.-An intercellular space resembling a canaliculus (C) with cell processes $(P)$ flanked by synovial cells $(S) . \quad \times 9,000$. 


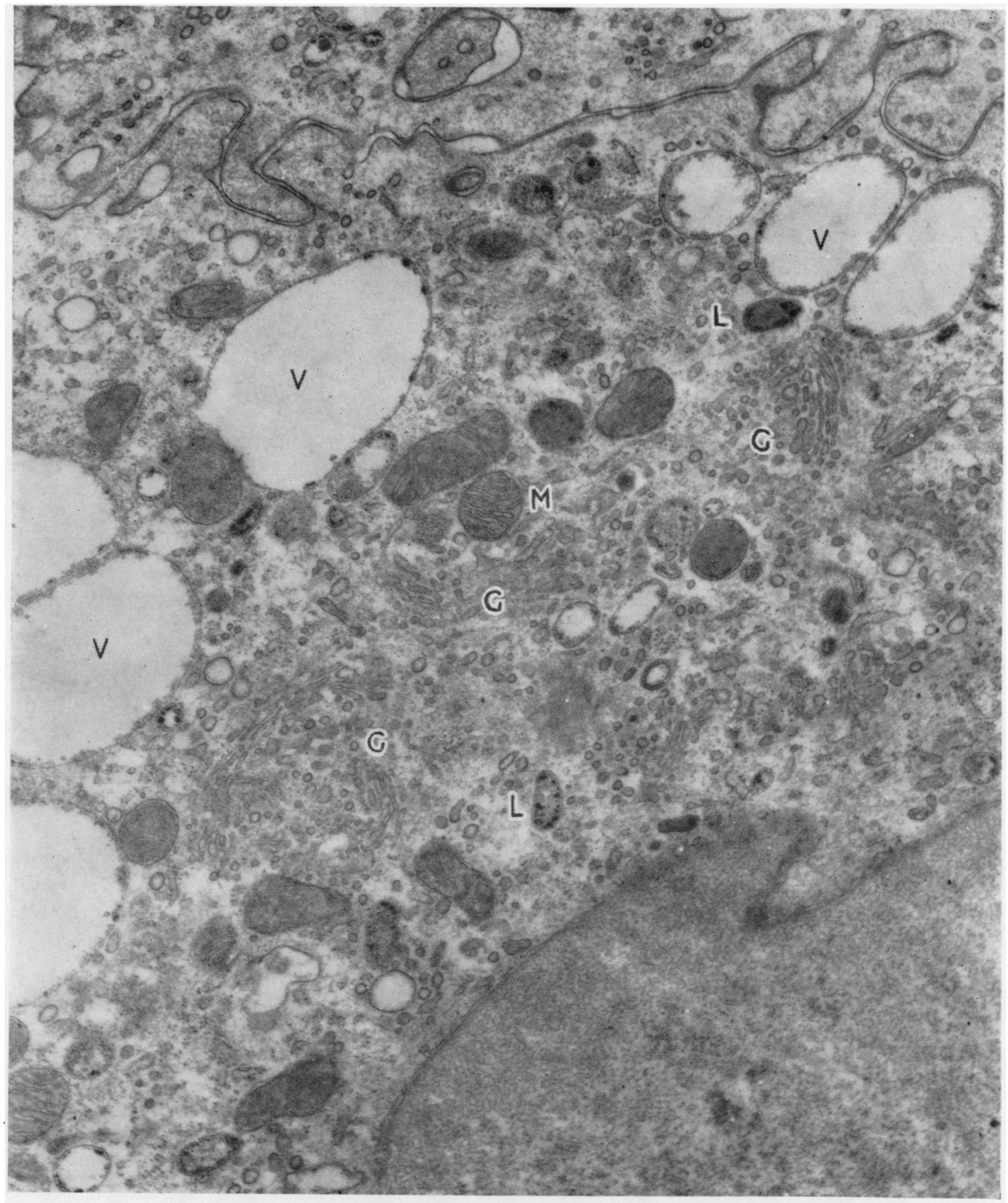

Fig. 4.-Type A synovial cell, showing many Golgi complexes (G),
mitochondria (M), large vacuoles (V), and lysosomes (L). $\times 20,000$.

응 
Some Type A cells had a large number of lysosome- rounded by a double membrane and at times conlike bodies (Fig. 5). Many of these bodies were sur-

tained structures resembling modified mitochondrial

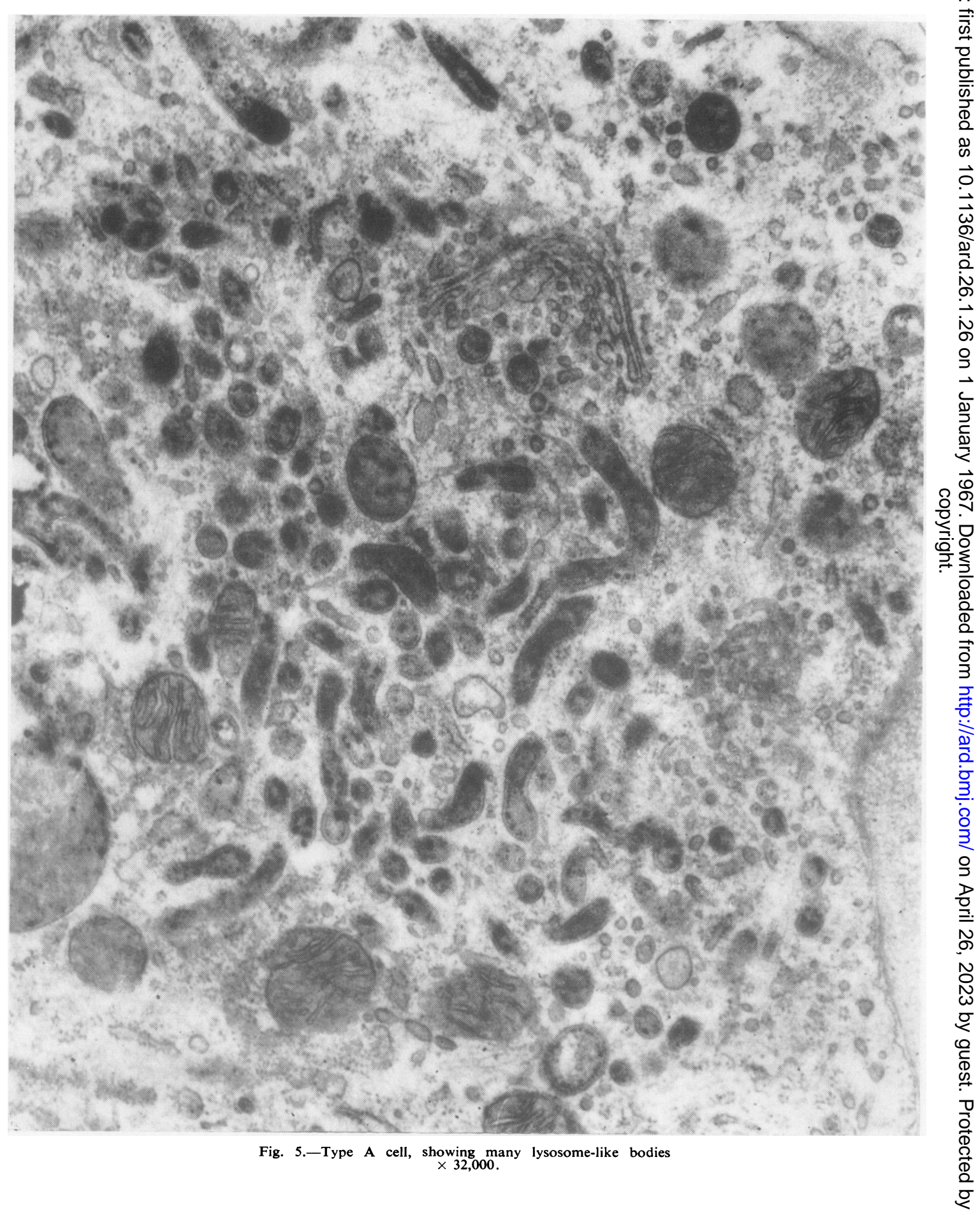


cristae (Fig. 6). Type B cells were well endowed with rough endoplasmic reticulum and contained only occasional Golgi systems and a few smooth-walled vesicles (Fig. 7). Both types of cell contained many mitochondria with well-defined cristae set in a medium density matrix. In the normal rat, the pure Type $\mathbf{B}$ synovial cell is only very rarely encountered. However many intermediate type cells showing both well-developed Golgi complexes and abundant rough endoplasmic reticulum were observed.

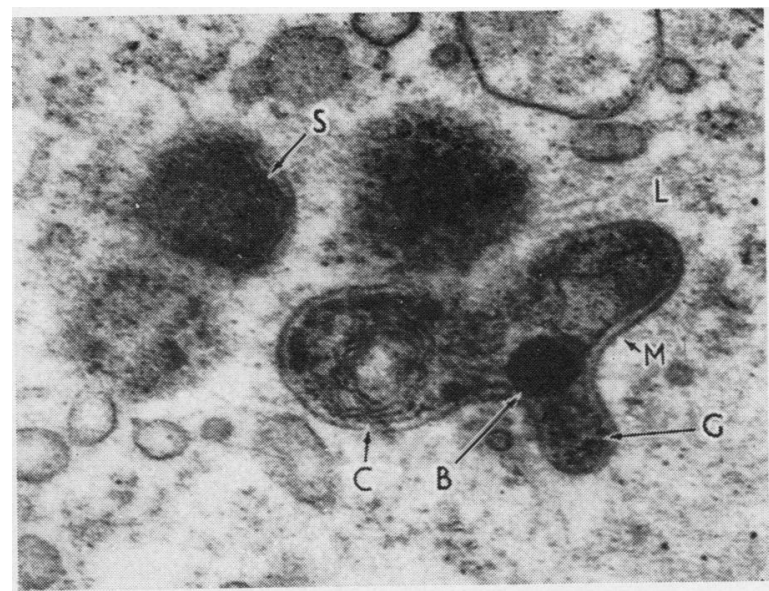

Fig. 6-A cytolysome of mitochondrial origin (L), limited by a double Fig. 6.- A cytolysome of mitochondrial origin (L), limited by a double membrane (M) and containing modified cristae (C), electron dense
bodies (B), and granules $(G)$. Three other ill-defined lysosomes, one bodies (B), and granules $(G)$. Three other ill-defined lysosomes, one
containing membranous structures $(S)$, can also be seen. $\times 54,000$.

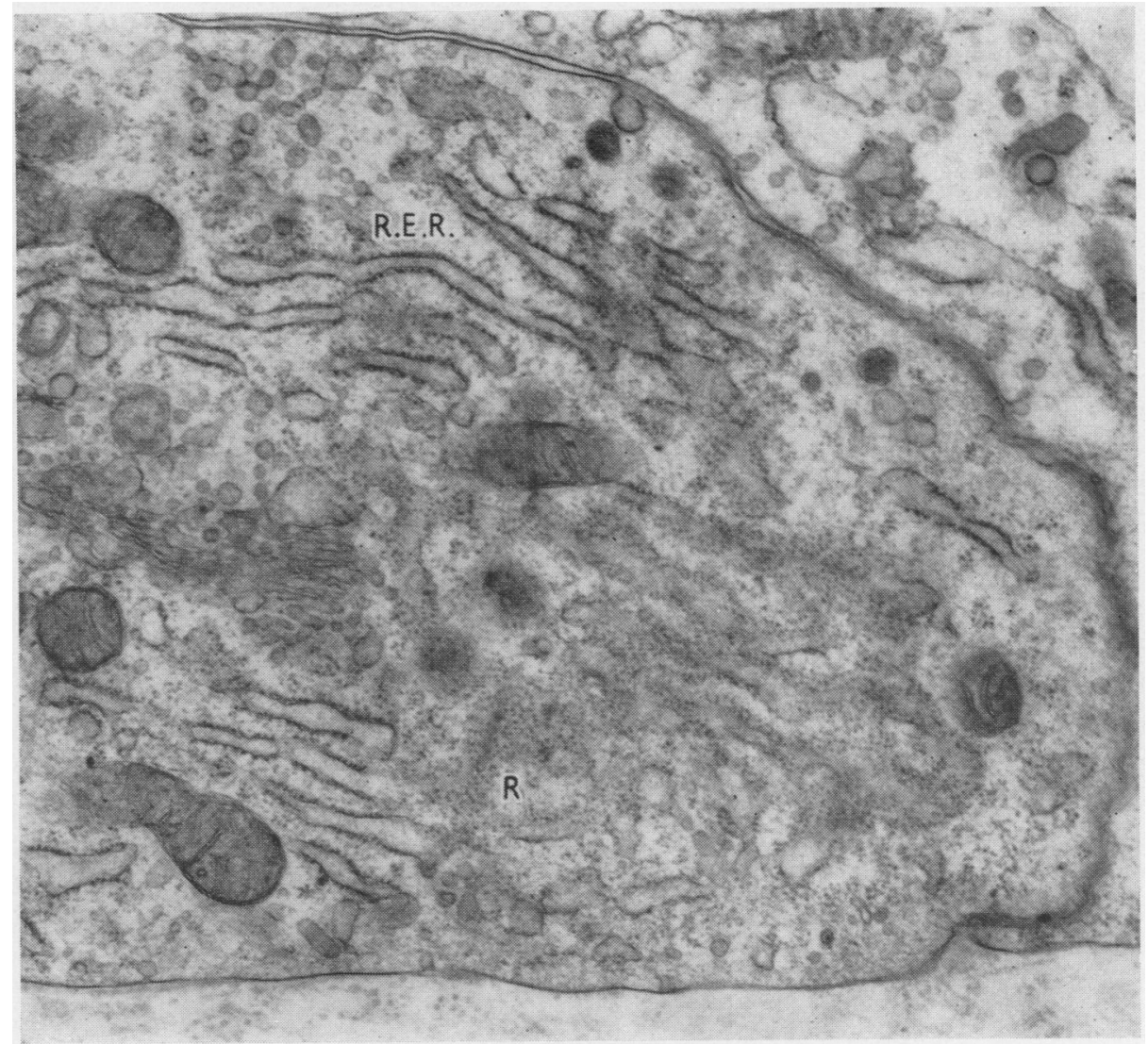

Fig. 7.-Type B synovial cell with well-developed rough endoplasmic reticulum (R.E.R.) and many free ribosomes (R). $\times 26,000$. 
A striking feature frequently seen was the occurrence of large multiple vacuoles in the cytoplasm of many Type A synovial cells. The contents of these spaces were electron lucent but at times a fine filamentous cobweb could be discerned (Fig. 8).
Cell Membrane.-Perhaps the most interesting finding in this study was the very close apposition of the cytoplasmic membranes of adjacent cells leading at times to the formation of structures resembling cell invaginations, tight junctions, and

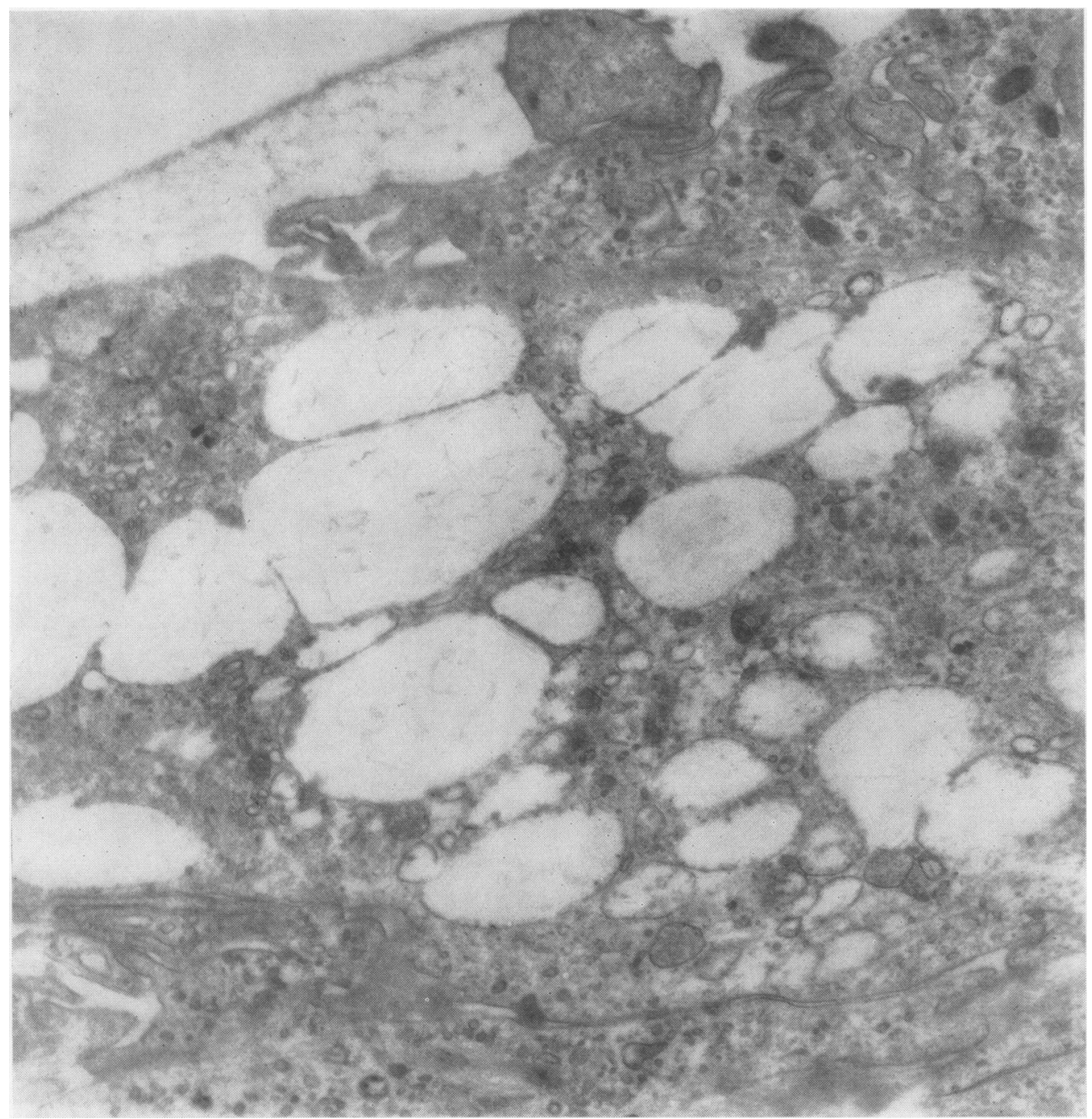

Fig. 8.-Type A synovial cell, showing many large vacuoles. $\times 12,000$. 
desmosomes, similar to that found in true epithelia. Invagination of adjacent cell surfaces was a common feature. These invaginations were composed of either small interdigitating finger-like processes (Fig. 9) or terminally expanded club-shaped projections apparently locking adjacent cells together (Fig. 10, overleaf).

At times adjacent cell membranes ran together and fused to form an electron dense line (Fig. 11, overleaf) flanked by a continuous band of amorphous electron dense substance. This appearance is reminiscent of tight junctions seen in epithelia. A study of many such zones leads us to believe that these appearances are not created by oblique sectioning of the cell membrane but represent true points of contact between cells. Of somewhat rarer occurrence was the development of localized button-like specializations of the plasma membrane resembling desmosomes (Figs 12 and 13, overleaf).

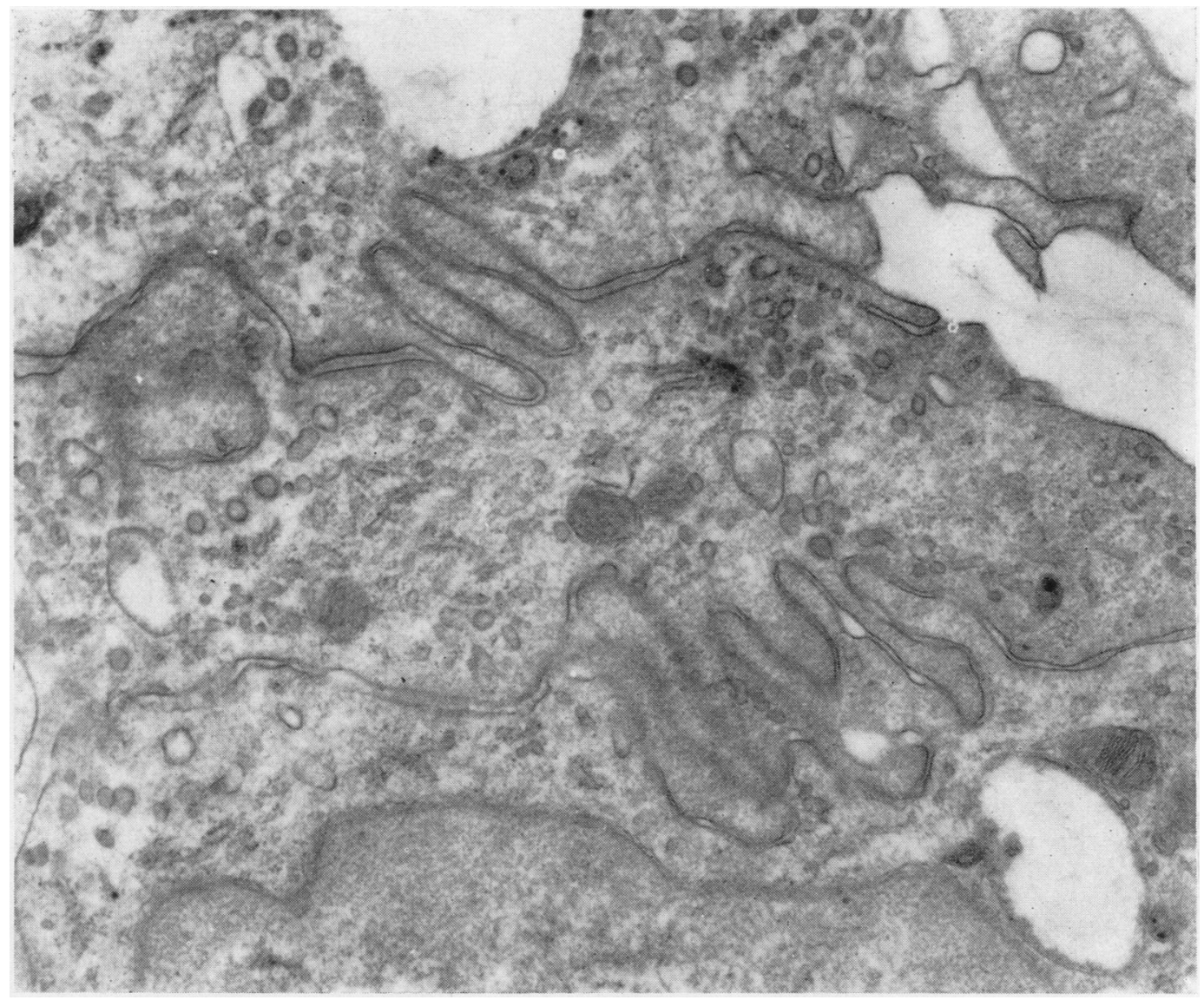

Fig. 9.-Synovial cells with interdigitating cell boundaries. $\times 24,000$. 


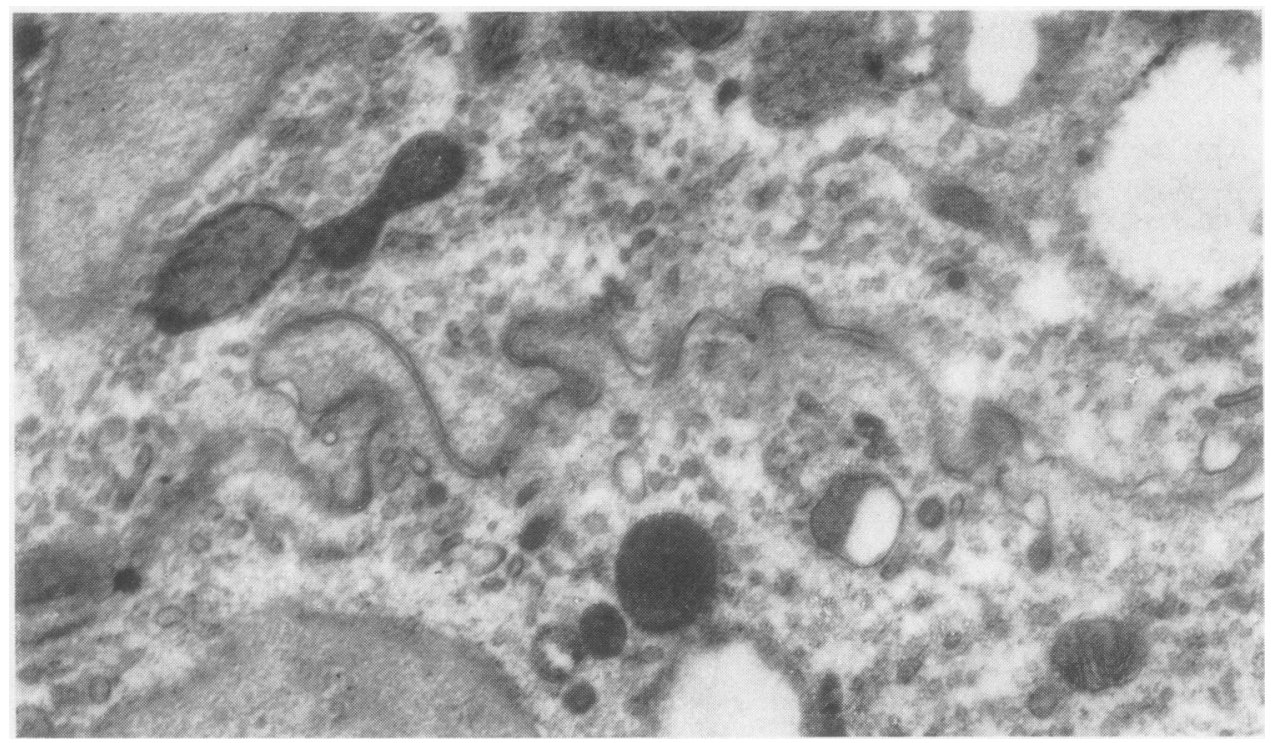

Fig. 10.-Synovial cells locked together by club-shaped invaginations of the cell borders. $\times 24,000$.

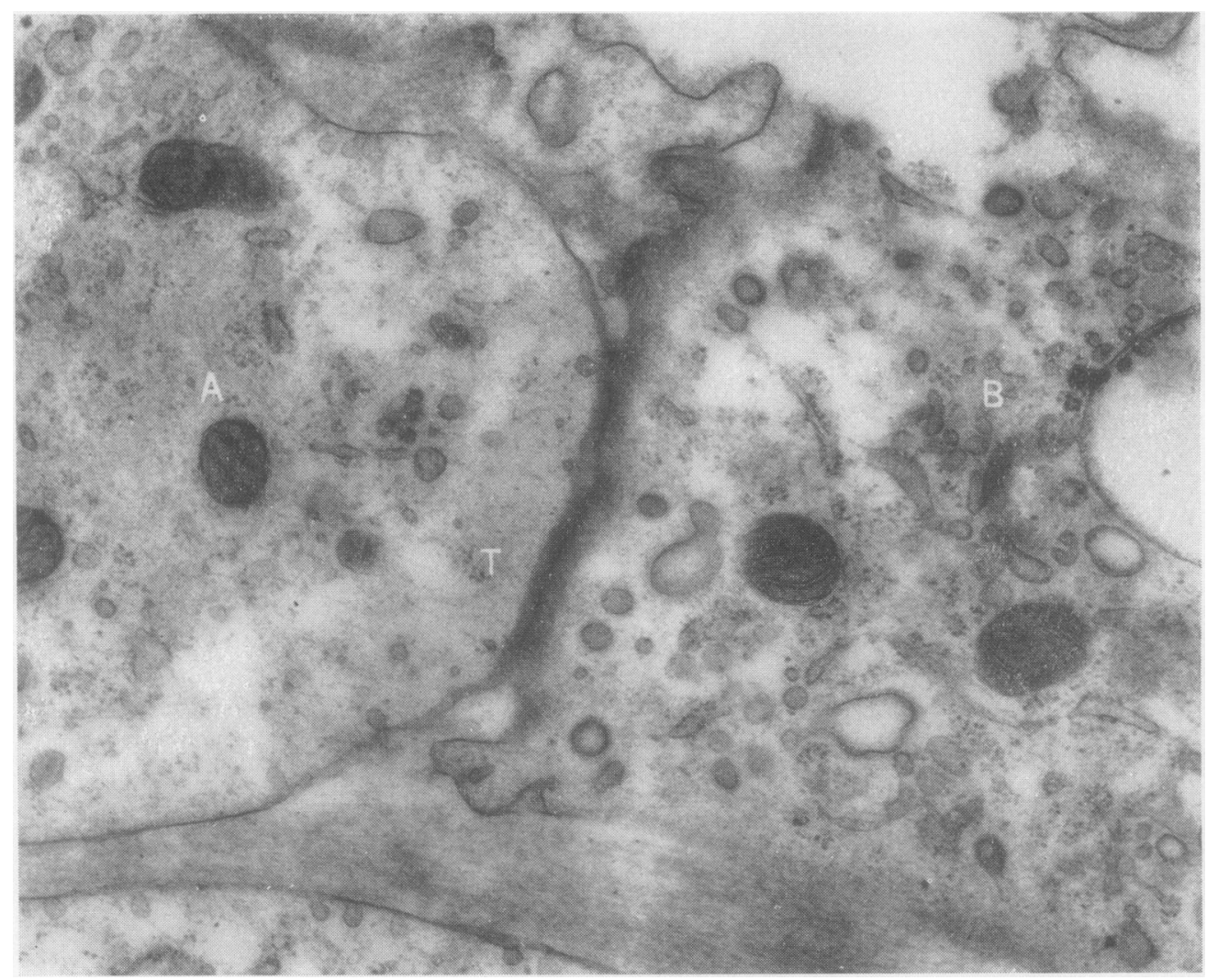

Fig. 11.-Cell membranes of two synovial cells (A and B) can be seen fused together forming a tight junction $(T) . \times 32,000$. 


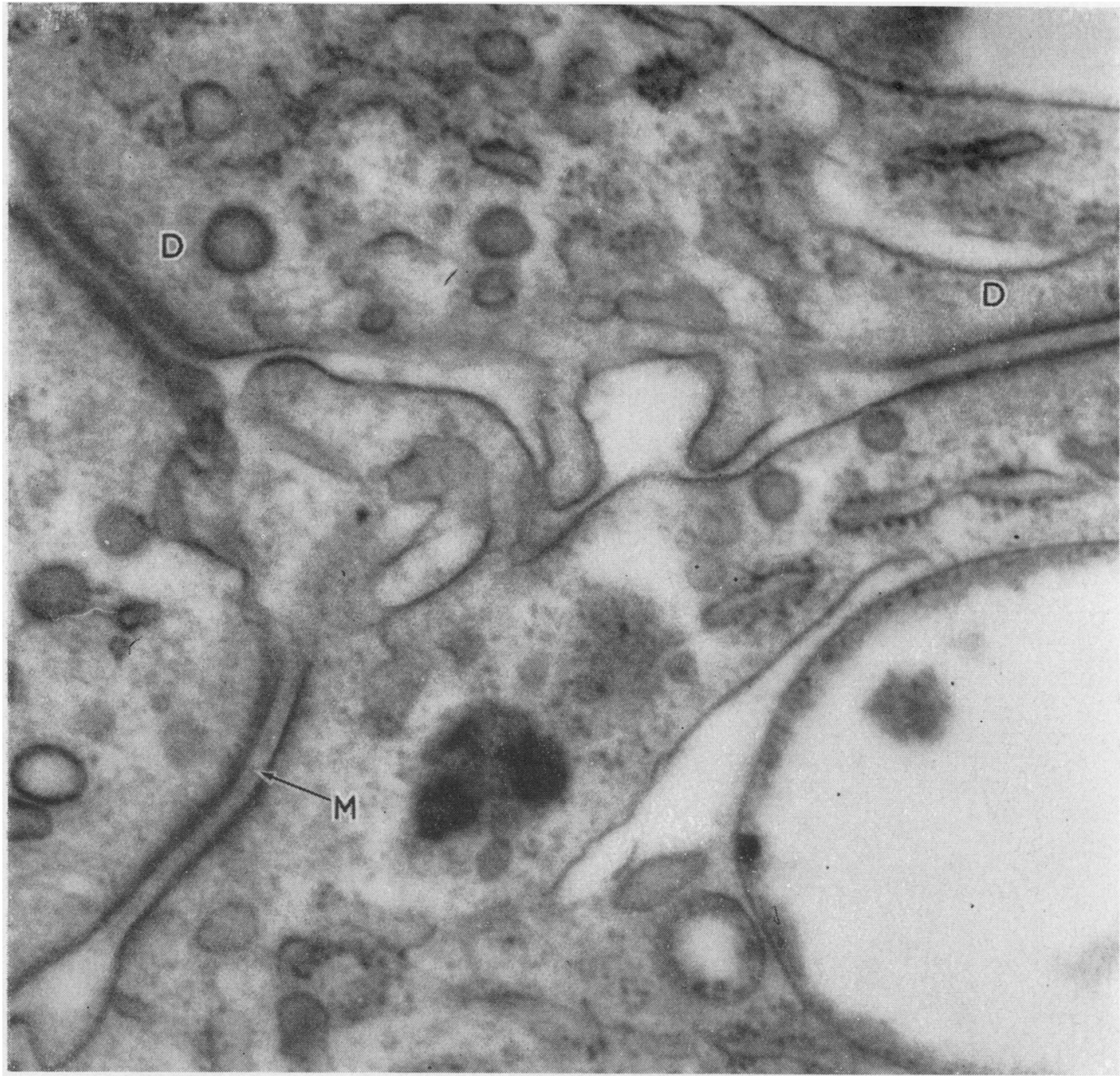

Fig. 12.-Desmosome-like structures (D) formed at the junction of synovial cells. Intercellular granular material (M) is well demonstrated. $\times 64,000$.

Fig. 13.-Desmosome-like structure formed at the ${ }^{\prime}$ junction of synovial cells. The characteristic condensation of cytoplasm and formation of fibrillary material (F) around these structures is well demonstrated. $\times 64,000$.

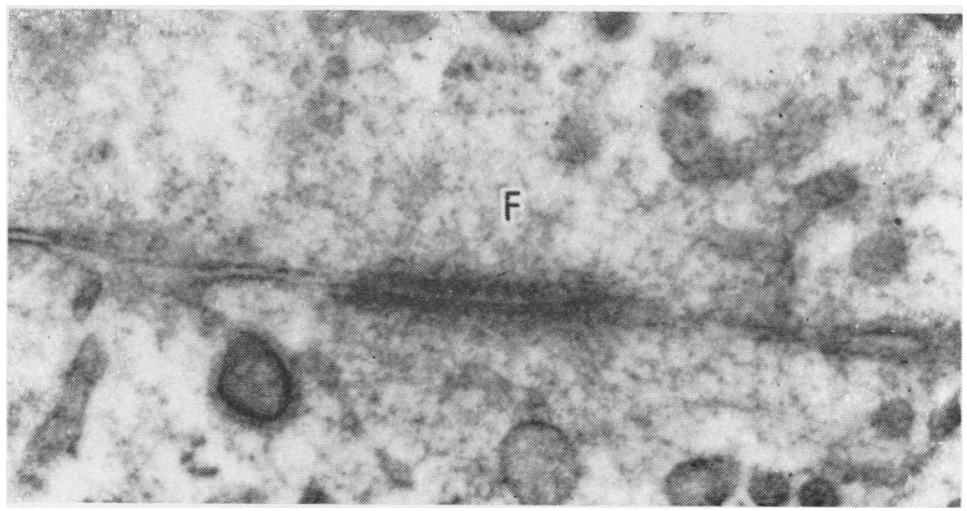


Matrix.-As already noted (Fig. 2), the matrix in the rat synovium is scanty. Nevertheless, as in the case of the rabbit, it is seen to contain periodicallybanded collagen fibres, aperiodic fibres, and granular material (Fig. 14). The periodic fibres occur freely in the deeper zone and only rarely can a few such fibres be found in the middle zone. The middle zone contains aperiodic fibres and granular material. The cells in the superficial part of the synovium are very closely packed and only rarely is a small amount of granular material seen in this region.

\section{Discussion}

The most outstanding difference between the rat synovium and that of other species so far studied is the occurrence of cell invaginations and structures resembling tight junctions and desmosomes. The synovial cells of other species lie loosely in a medium density matrix and hence present a discontinuous layer facing the joint cavity. However, occasionally two synovial cells may lie close together (Ghadially and Roy, 1966) or their processes may interdigitate (Barland and others, 1962), but complex invaginations of the cell membranes and structures resembling tight junctions and desmosomes do not occur. Focal specialization of the plasma membrane at cell surface is common enough in epithelial cells of various organs (Farquhar and Palade, 1963) and tight junctions are also known to occur between mesothelial cells lining the pleural and pericardial

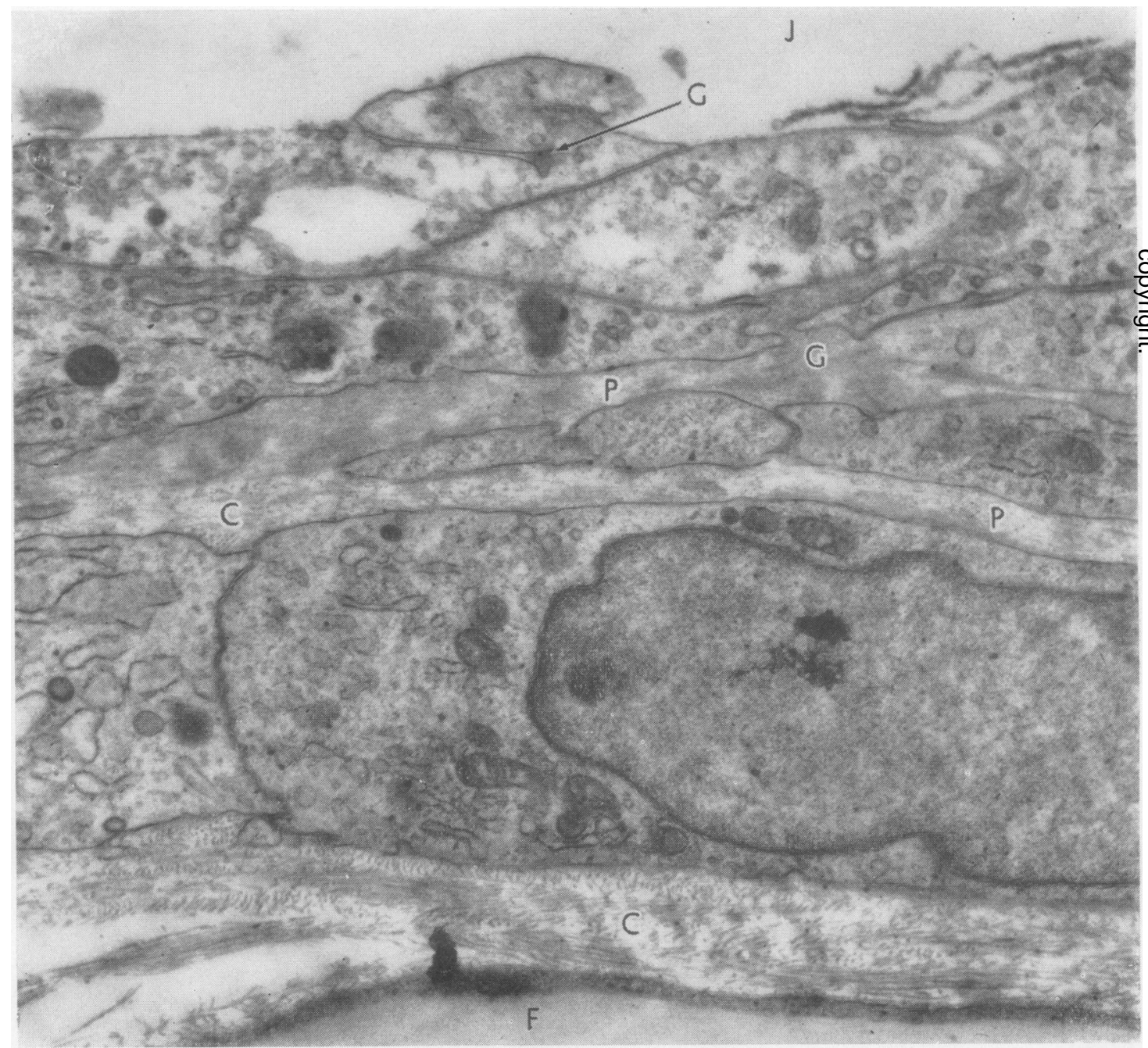

Fig. 14.-Low-power view of synovium, showing distribution of collagen fibres (C), aperiodic fibres (P), and granular material (G) in various zones of the matrix, joint space $(J)$ and subsynovial fat cell $(F) . \times 11,000$. 
cavity of the rabbit (Luse, 1960), but it is the first time that it has been recorded to occur in the synovium. Obviously this is a species difference for so far only the rat has shown this peculiar morphology but the significance of this phenomenon is obscure.

Another feature which distinguishes rat synovium from that of other animals is the occurrence of cells with an unusually large number of bodies which can be interpreted as lysosomes. Since some of these are limited by a double membrane and contain membranous structures resembling cristae, it is legitimate to assume that these are cytolysomes of mitochondrial origin probably arising by a process of focal cytoplasmic degeneration (Novikoff and Essner, 1962; Napolitano, 1963; Parry and Ghadially, 1965).

Although a substantial amount of synovial matrix is lacking in the superficial zone of the synovium in the rat, the distribution of periodic fibres, aperiodic fibres, and granular matrix shows a broadly similar pattern of arrangement to that seen in the rabbit (Ghadially and Roy, 1966). For once again we find that periodically-banded collagen which occurs mainly in the deepest zone is replaced by aperiodic fibres and granular material as we move towards the more superficial regions of the synovium. In the rat too then, the appearances seen are consistent with the idea that there may be a gradual disintegration of collagen to form first aperiodic fibres and later the granular material of the matrix (Ghadially and Roy, 1966).

\section{Summary}

Two types of cells can be detected in the rat synovium. The Type A cell is characterized by a prominent Golgi system, many smooth vesicles, and large vacuoles, while the Type B cell contains abundant rough endoplasmic reticulum. Type B cells were of infrequent occurrence but many intermediate forms showing features of both types of cells were frequently seen. In contrast to the cells of the synovial membrane of other species, the cells of rat synovium form a more or less continuous layer facing the joint cavity. The adjacent cell walls show many invaginations and also structures resembling tight junctions and desmosomes. The synovial matrix contained mainly banded collagen in the deepest zone while the middle zone showed many aperiodic fibres and granular material. Only an occasional small pocket of granular matrix is found in the superficial zone of the synovium.

This work was supported by a grant from the Arthritis and Rheumatism Council. We are grateful to $\mathrm{Mr}$. A. Ridge and Miss Ann Malone for their technical assistance.

\section{REFERENCES}

Barland, P., Novikoff, A. B., and Hamerman, D. (1962). J. Cell Biol., 14, 207 (Electron microscopy of the human synovial membrane).

Coulter, W. H. (1962). Arthr. and Rheum., 5, 70 (The characteristics of human synovial tissue as seen with the electron microscope).

Farquhar, M. G., and Palade, G. E. (1963). J. Cell Biol., 17, 375 (Junctional complexes in various epithelia).

Ghadially, F. N., and Roy, S. (1966). Ann. rheum. Dis., 25, 318 (Ultrastructure of rabbit synovial membrane).

Glauert, A. M. (1961). In "Techniques for Electron Microscopy”, ed. D. Kay, pp. 179-181. Blackwell, Oxford.

Langer, E., and Huth, F. (1960). Z. Zellforsch., 51, 545 (Untersuchungen uber den submikroskopischen Bau der Synovial Membran).

Lever, J. D., and Ford, E. H. R. (1958). Anat. Rec., 132, 525 (Histological, histochemical and electron microscopic observations on synovial membrane).

Luse, S. A. (1960). Cancer, 13, 312 (A synovial sarcoma studied by electron microscopy).

Napolitano, L. (1963). J. Cell Biol., 18, 478 (Cytolysomes in metabolically active cells).

Novikoff, A. B., and Essner, E. (1962). Ibid., 15, 140 (Cytolysomes and mitochondrial degeneration).

Palade, G. E. (1952). J. exp. Med., 95, 285 (A study of fixation for the electron microscope).

Parry, E. W., and Ghadially, F. N. (1965). Cancer, 18, 1026 (Ultrastructure of carcinogen-induced rat sarcoma).

Reynolds, E. S. (1963). J. Cell Biol., 17, 208 (The use of lead citrate at high $p \mathrm{H}$ as an electron-opaque stain in electron microscopy).

Roy, S., Ghadially, F. N., and Crane, W. A. J. (1966). Ann. rheum. Dis., 25, 259 (Synovial membrane in traumatic effusion. Ultrastructure and autoradiography with tritiated leucine).

Wyllie, J. C., More, R. H., and Haust, M. D. (1964). Lab. Invest., 13, 1254 (The fine structure of normal guinea-pig synovium).

\section{L'ultrastructure de la membrane synoviale normale chez le rat}

\section{RÉSUMÉ}

On peut mettre en évidence deux types de cellules dans la membrane synoviale du rat. La cellule de type A est caractérisée par un appareil de Golgi bien apparent, de nombreuses vésicules lisses, et de grandes vacuoles tandis que la cellule de type $B$ contient un réticulum endoplasmique abondant et grossier. Les cellules de type B étaient peu fréquentes mais on voyait beaucoup de formes intermédiaires présentant des caractères appartenant à chacun des deux types de cellules. Contrairement aux cellules observées dans la membrane synoviale d'autres espèces, celles de la synoviale de rat forment une couche plus ou moins continue faisant face à la cavité articulaire. Les parois cellulaires adjacentes présentent de nombreuses invaginations et aussi des structures ressemblant à des jonctions étroites et à des desmosomes. La matrice 
synoviale contient principalement du collagène en faisceaux dans la zone la plus profonde tandis que dans zone moyenne on observe de nombreuses fibres apériodiques et beaucoup de matériel granulaire. Ce n'est que rarement que l'on voit des pochettes de matrice granulaire dans la zone superficielle de la synoviale.

\section{La ultrastructura de la sinovia normal de la rata}

\section{Sumario}

Dos tipos de células pueden evidenciarse en la sinovia de la rata. La célula del tipo A se caracteriza por un destacado aparato de Golgi, muchas vesículas lisas y grandes vacuolas, mientras que la célula del tipo B contiene un retículo endoplásmico grosero y abundante. Las células del tipo B fueron poco frecuentes, pero se pudieron ver muchas formas intermedias con rasgos de ambos tipos de células. Contrariamente a las células de la membrana sinovial de otras especies, las células de la sinovia de la rata forman una capa más o menos contítua frente a la cavidad articular. Las paredes celulares adyacentes presentan numerosas invaginaciones así como estructuras que se parecen a estrechas uniones y a desmosomas. La matriz sinovial contiene principalmente colágeno congregado en la zona más profunda, mientras que en la zona intermedia se observan numerosas fibras aperiódicas y material granular. Sólo a veces se encuentran pequeñas bolsas de matriz granular en la zona superficial de la sinovia. 